\title{
Měřicí vozidlo Ústavu soudního inženýrství
}

\section{The Testing Vehicle at Institute of Forensic Engineering}

\author{
Pavel Maxera*, Michal Belák, Marek Semela
}

Vysoké učeni technické v Brně, Ústav soudního inženýrstvi

\begin{abstract}
Abstrakt
Článek představuje nové testovací vozidlo Ústavu soudního inženýrstvi VUT v Brně, které bylo pořízeno pro účely rozšíření výukových možnost pro studenty magisterského studia $\mathrm{v}$ oblasti expertního inženýrství v dopravě. Plně vybavené moderní vozidlo prvky aktivní a pasivní bezpečnosti v kombinaci s měřicí soustavou pro monitoring chování řidičù umožňuje sběr dat o chování a stavu řidičů v běžném silničním provozu.
\end{abstract}

Klíčová slova: testovací vozidlo, aktivní bezpečnost, řidič, chování, vnímání, biosignály, eyetracking

\section{MĚŘICÍ VOZIDLO}

$\mathrm{V}$ rámci projektu spolufinancovaného EU s názvem Podpora rozvoje studijního prostředí na VUT (ROSTU) bylo v roce 2018 na Ústavu soudního inženýrství VUT v Brně pořízeno pro výukové účely měřicí vozidlo, jehož účelem je seznámit studenty s možnostmi měření chování řidičů a s nejmodernějšími asistenčními a bezpečnostními systémy, které se v současné době montují převážně do vozidel vyšších kategorií. Tyto prvky si postupně nacházejí cestu i do běžnějších a dostupnějších vozidel. Př́ikladem může být adaptivní tempomat, který byl před pár lety výsadou nejluxusnějších značek, ale v současnosti je možné si ho pořídit i do „běžné“ Octavie. V principu jde tedy o to, aby byly studentům $\mathrm{v}$ rámci praktické výuky předávány co nejaktuálnější informace nejen po stránce teoretické, ale i po stránce praktické. Mezi požadavky výběrového řízení na moderní plně vybavené vozidlo se tedy nacházely napr. prvky jako asistent jízdy v pruzích, noční vidění, head-up display, asistent dopravního značení, aktivní/ adaptivní tempomat s funkcí udržování vzdálenosti a krizového brzdění, asistent udržování vozidla v pruzích, varování při opuštění

\begin{abstract}
Article introduces the new testing vehicle at the Institute of Forensic engineering of Brno University of Technology. The vehicle expands the learning opportunities for master's degree students in the field of expert engineering in traffic. Modern vehicle fully equipped with active and passive safety assistants in combination with the measuring tool for monitoring of driver's behavior enables data collection aimed at status and behavior of drivers in regular road traffic.
\end{abstract}

Keywords: testing vehicle, active safety, driver, behavior, perception, biosignals, eyetracking

jízdního pruhu, systém upozorňující na nebezpečí kolize, asistent dálkových světel, systém hlídání mrtvého úhlu aj.

Aby bylo dále např. možné vliv těchto systémů na řidiče měřit a vyhodnocovat, bylo nutné, aby bylo vozidlo vybaveno sofistikovaným měřicím zařízením umožňujícím v jednotném čase měřit a zaznamenávat rozmanitá data, jako např́klad směr úhlu pohledu řidiče, situaci před vozidlem (svislé a vodorovné dopravní značení, pohyb a vzdálenost od vozidel a chodců), vozidlová data (CAN data), polohu vozidla pomocí GPS, různá fyziologická data (činnost svalů/EMG, teplota a vodivost kůže, srdeční rytmus/EKG aj.) a také dění ve vozidle a okolo něho pomocí kamer a mikrofonů.

Zadaným požadavků vyhovělo vozidlo BMW 530dX a měřicí souprava Vehicle Testing Kit od společnosti Ergoneers, které je v současnosti špičkou ve svém oboru. Zařízení se skládá z počítače a měřicích a analytických modulů, které lze modifikovat dle oblasti výzkumu. Vše je řízeno softwarem D-Lab, který umožňuje plánovat, měřit a vyhodnocovat $\mathrm{v}$ jednotném čase různá data $\mathrm{z}$ prripojených zařízení a snímačů o chování řidiče (eyetracking, video, audio) a o vozidle (CAN data, Mobileye ${ }^{\circledR}$, GPS). Ústav soudního inženýrství VUT v Brně dále také disponuje modulem pro sběr biosignálů řidiče. 


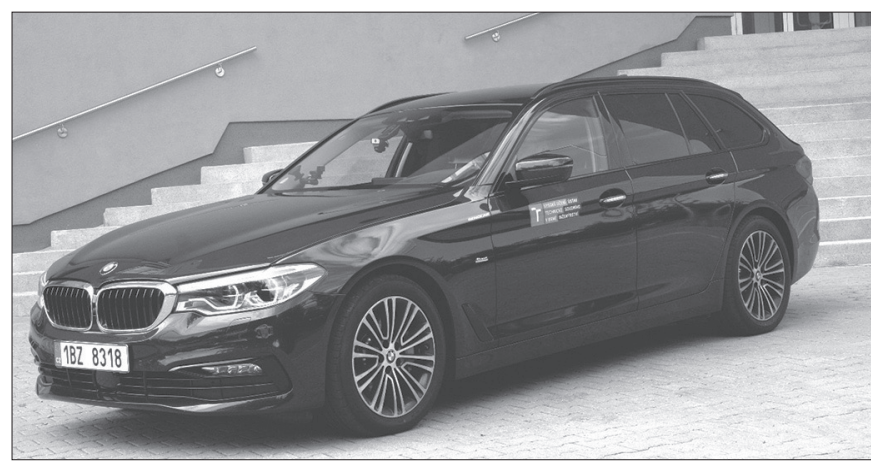

Obr. 1 Měricí vozidlo.

Fig. 1 Testing vehicle.

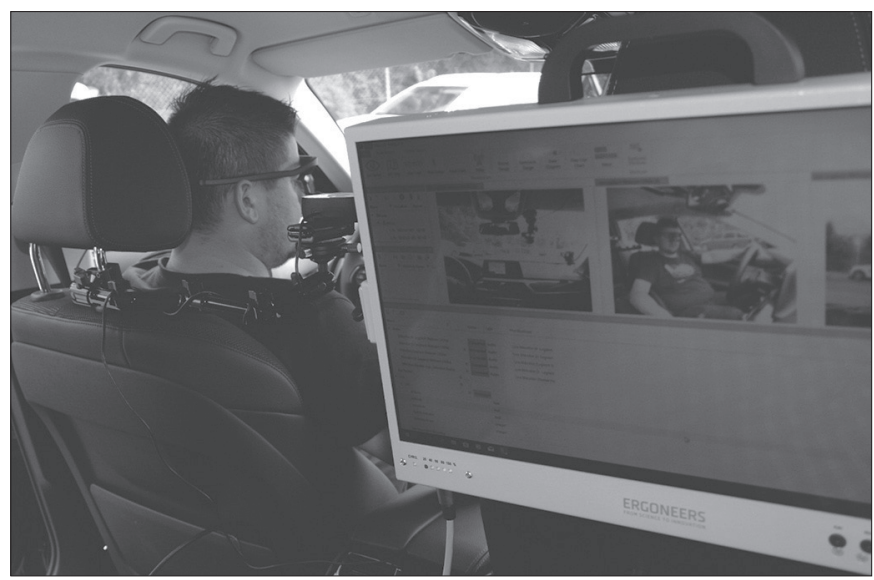

Obr. 3 Testovací ridič a vyhodnocovaci software.

Fig. 3 Tested driver and software for evaluation.

Velkou výhodu daného zařízení lze spatřovat v tom, že dokáže naměřená data poloautomaticky vyhodnocovat pomocí softwaru D-Lab, a to díky dobré kompatibilitě připojených modulů, např. modul Mobileye ${ }^{\circledR}$ kromě jiných funkcí zaznamenávání dat z vozidla a dopravního prostředí (dopravní značky, jízdní pruhy apod.) dokáže sám detekovat vozidla (ve dne na $150 \mathrm{~m}$, v noci na $90 \mathrm{~m}$ ) i chodce (ve dne na $40 \mathrm{~m}$ ).

Díky tomuto vybavení bude možné dále rozšiřit znalosti v oblasti chování řidiče $\mathrm{v}$ reálném silničním provozu a jeho ovlivněním pokročilými asistenty. Dále bude možné podrobněji zkoumat reakční dobu řidiče mj. i pomocí dostupných a měřitelných biosignálů, resp. také ovlivnění řidiče jinými podněty, únavou, stresem apod.

Ústav soudního inženýrství VUT v Brně se stal jediným v České republice, který disponuje tímto kompletním zařízením pro posuzování bezpečnosti $\mathrm{v}$ dopravě $\mathrm{v}$ moderním vozidle. Zcela jistě

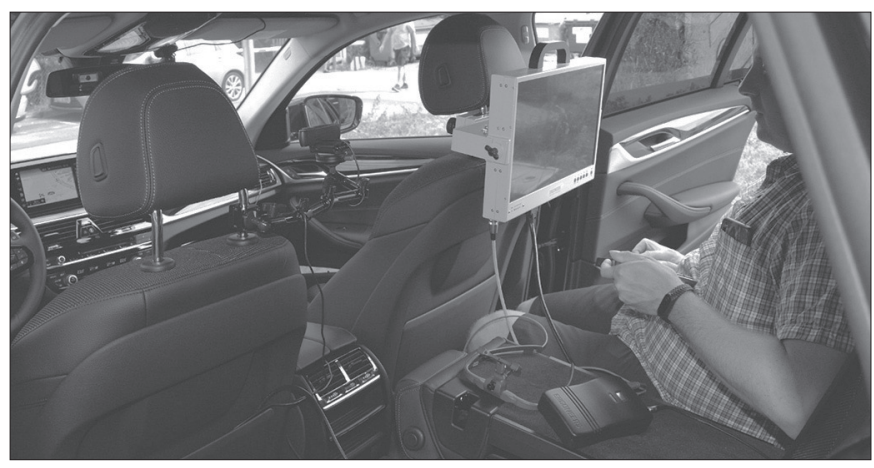

Obr. 2 Ovládací monitor a vnitřní vybavení.

Fig. 2 Controlling monitor and measuring equipment.

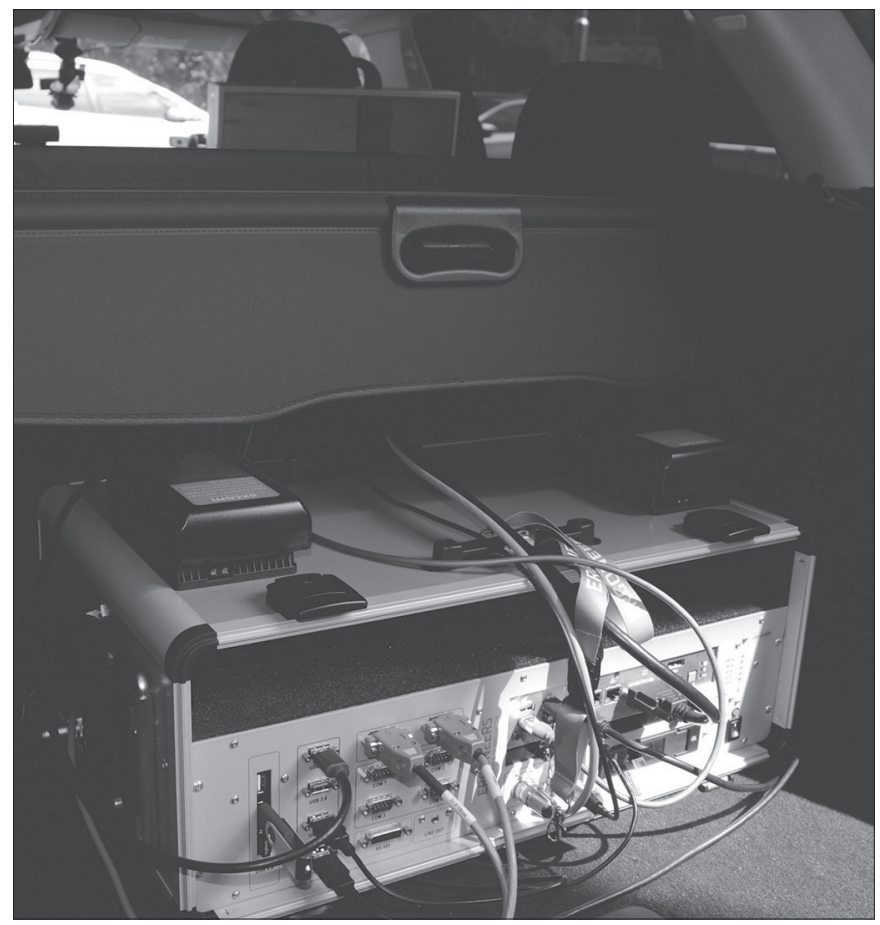

Obr. 4 Ergoneers $P C$.

Fig. Ergoneers $P C$.

tak pořízení a využití vozidla vč. zařízení Ergoneers a všech modulů přidá Ústavu soudního inženýrství, ale i celému Vysokému učení technickému v Brně na kredibilitě v jeho výukových činnostech a umožní tak zvýšení kompetencí absolventů.

Měřicí vozidlo bude možné zhlédnout v rámci akce Crashday ve dnech 14. až 15. 9. 2018 v Ostrovačicích u Brna (www.crashday. cz) a dalších akcích, které ústav organizuje, např. konferenci ExFoS (www.exfos.cz).

\section{Správná citace:}

MAXERA, P., BELÁK, M., SEMELA, M. Měřicí vozidlo Ústavu soudního inženýrství. Soudní inženýrství, 2018, 29(3), 54-55. ISSN 1211-443X. 